\title{
Screening of ligands for the Ullmann synthesis of electron-rich diaryl ethers
}

Nicola Otto and Till Opatz

\section{Full Research Paper}

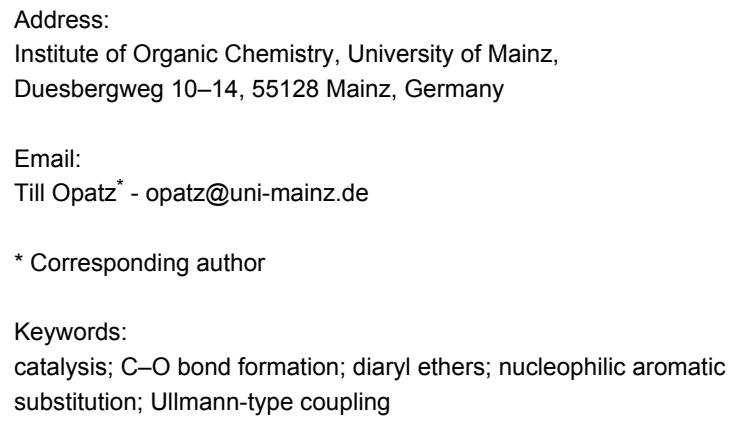

Beilstein J. Org. Chem. 2012, 8, 1105-1111.

doi:10.3762/bjoc.8.122

Received: 27 April 2012

Accepted: 04 July 2012

Published: 17 July 2012

Associate Editor: M. Rueping

() 2012 Otto and Opatz; licensee Beilstein-Institut.

License and terms: see end of document.

\begin{abstract}
In the search for new ligands for the Ullmann diaryl ether synthesis, permitting the coupling of electron-rich aryl bromides at relatively low temperatures, 56 structurally diverse multidentate ligands were screened in a model system that uses copper iodide in acetonitrile with potassium phosphate as the base. The ligands differed largely in their performance, but no privileged structural class could be identified.
\end{abstract}

\section{Introduction}

The diaryl ether linkage is a common structural motif encountered in numerous classes of natural products. Moreover, various diaryl ethers have been shown to possess antibacterial, anti-inflammatory, antifungal and herbicidal activity, rendering this compound class attractive for pharmaceutical and agrochemical research [1,2]. Prominent examples of bioactive natural representatives include the glycopeptide antibiotic vancomycin $[3,4]$, the bisbenzylisoquinolines tubocurarine [5] and tetramethylmagnolamine [6], and the antifungal diamine piperazinomycin [7] (Figure 1).

A straightforward method for the formation of diaryl ethers is the Cu-catalyzed coupling of aryl halides with phenols, first reported by Fritz Ullmann in 1903 [8,9]. However, the classical protocol suffers from considerable limitations due to the use of stoichiometric or superstoichiometric amounts of copper powder and typically requires high reaction temperatures $\left(\approx 200{ }^{\circ} \mathrm{C}\right)$, thus tolerating only a limited number of functional groups. Alternatively, $\mathrm{C}-\mathrm{O}$ bond formation can be accomplished by efficient Pd-catalyzed arylations of phenols developed by Buchwald [10,11] and Hartwig [12,13] in the 1990s. Nevertheless, the use of this expensive metal in combination with sensitive and costly phosphine ligands limits the use of palladium catalysis for industrial-scale applications and economic aspects have led to a renaissance of the $\mathrm{Cu}$-catalyzed reaction in recent years [14]. It is known that certain additives, such as $\mathrm{N}, \mathrm{N}$ - and $\mathrm{N}, \mathrm{O}$-chelating ligands, accelerate the Ullmann diaryl ether synthesis and permit a considerable reduction of the 


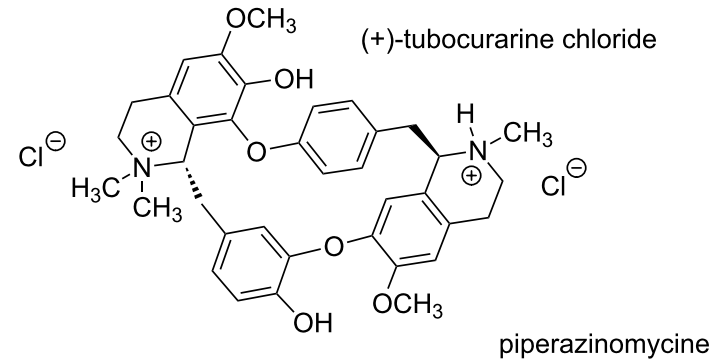

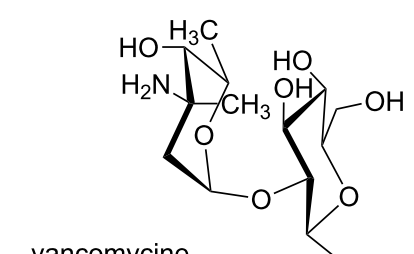

$\mathrm{OH}$<smiles>Oc1ccc2cc1Oc1ccc(cc1)CC1CNC(C2)NC1</smiles>

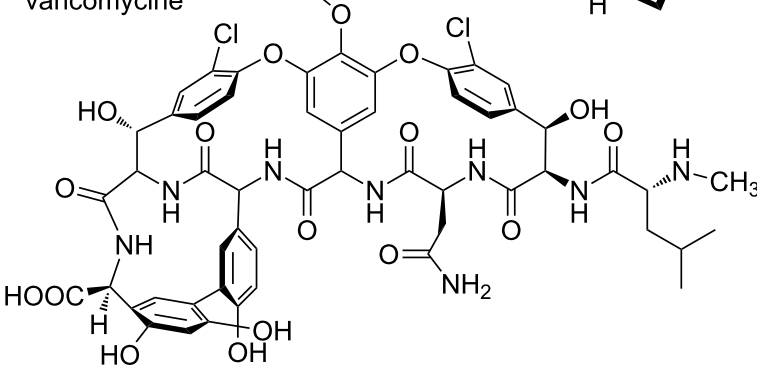<smiles>COc1cc(C[C@H]2c3cc(OC)c(OC)cc3CCN2C)c(Oc2ccc(C[C@@H]3c4cc(OC)c(OC)cc4CCN3C)cc2)cc1OC</smiles>

Figure 1: Selected examples of bioactive natural diaryl ethers.

reaction temperature [15-17]. Successful approaches towards a mild coupling were, e.g., developed by Taillefer and Buchwald in 2003 and 2004 who used multidentate ligands and a 5-10 mol \% catalyst loading at $90-110{ }^{\circ} \mathrm{C}$ [18-20]. However, the majority of ligands reported in the literature to date exhibit a limited substrate scope, and application of the methodology to more complex molecules is still challenging.

For the synthesis of alkaloids containing the diaryl ether linkage, we searched for efficient ligands for the Ullmann coupling of electron-rich aryl bromides as the substrates and performed a ligand screening using the model system 4-bromoanisole/4-methoxyphenol. To the best of our knowledge, this represents the most diverse ligand set investigated for a similar purpose so far [21].

\section{Results and Discussion}

A set of 56 multidentate ligands with different chelating functionalities and bite angles, belonging to the structural classes of amino acids, acetic acid derivatives, phosphinites, phosphonates, imines, diimines, oximes, oxime ethers and diketones were selected for the screening (Figure 2). Several of these compounds have been employed in diaryl ether syntheses before [22-24].

As a starting point, $N, N$-dimethylglycine (L1) introduced by $\mathrm{Ma}$ et al. [22,25] in combination with copper iodide as the $\mathrm{Cu}$-source was chosen, as this ligand has been successfully applied by us in a synthesis of two dimeric benzylisoquinoline alkaloids [26]. This model system was optimized with respect to the influence of different bases, molecular sieves, solvents, and temperatures (Table 1).

It turned out that caesium carbonate as a base without addition of molecular sieves did not result in any diaryl ether formation, presumably due to the formation of water inactivating the base. With chemical drying agents such as magnesium sulfate, only trace amounts of the product were obtained. In contrast, potassium phosphate proved to be a more suitable base for diaryl ether formation and did not require the addition of molecular sieves. After screening of different solvents, the combination of copper(I) iodide (10 mol \%), N,N-dimethylglycine L1 $(10 \mathrm{~mol} \%)$ as the ligand, potassium phosphate (2.0 equiv) as the base and acetonitrile as solvent $\left(80^{\circ} \mathrm{C}\right)$ was identified as an efficient system for the coupling of the above-mentioned starting materials $(1.0 \mathrm{mmol}$ each in $0.6 \mathrm{~mL})$. Although the substrate conversion in acetonitrile at $80{ }^{\circ} \mathrm{C}$ was lower than in toluene at $110{ }^{\circ} \mathrm{C}$ (Table 1 , entries 5 and 7), acetonitrile was selected as the solvent for the ligand screening in order to be able to compare ligands that give higher conversions than $\mathbf{L 1}$ and to get a better impression of the respective reaction rates. The substrate conversion of the screening reactions was monitored and determined by ${ }^{1} \mathrm{H}$ NMR spectroscopy at specific time intervals (2 $\mathrm{h} 15 \mathrm{~min}$ and $24 \mathrm{~h}$ ).

In the short-term screening, promising results were obtained with $N, P$-chelating phosphinite ligands such as $\mathbf{L 1 9}$ and L20, amino acid-derived $N, O$-ligands such as $\mathbf{L 2}$ and $\mathbf{L 3}$ and $N, O$ and $N, N$-ligands with a rigid backbone such as 8 -aminoquinoline (L44) and 8-hydroxyquinoline (L47) (Table 2 and Figure 3). These ligands have been reported to be effective in the $\mathrm{Cu}$-catalyzed diaryl ether synthesis before [21,27-29].

A disadvantage of ligands with free amino or hydroxy groups, such as L44, is that they themselves can act as substrates in the Ullmann-type coupling, which may result in the formation of undesired side products and a loss in catalyst performance. To 
<smiles>CNc1cccc(C(=O)O)c1NC</smiles>

$n=2 \mathrm{~L} 3$<smiles>CCCCN1CCCC1CC(=O)O</smiles>

$n=1$ L9

L10

L11

$n=2$ L15<smiles>[R2]P([R2])Oc1cccc2cccnc12</smiles><smiles>[R1][R1]SC[C@H](NC(C)=O)C(=O)O</smiles><smiles>CC(C)(C)C(=O)c1cccc(C(=O)O)n1</smiles>
L13

$\mathrm{R}^{1}=\mathrm{H} \quad \mathrm{L} 17$<smiles>c1ccc(P(CCCP(c2ccccc2)c2ccccc2)c2ccccc2)cc1</smiles>

L22 L23<smiles>O=C(O)c1ccccc1P(c1ccccc1)c1ccccc1</smiles>

L24

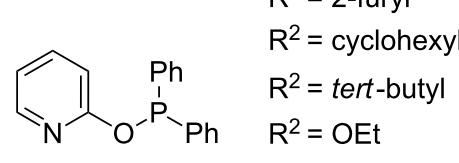

$\mathrm{R}^{2}=2$-furyl

L19

L20

L26

L27

\section{L25}

$\mathrm{R}^{2}=\mathrm{OEt}$<smiles>O=P(Oc1cccc2cccnc12)(c1ccccc1)c1ccccc1</smiles>

L21

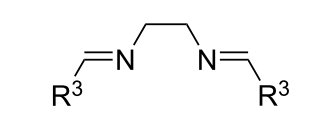

$\mathrm{R}^{3}=2$-thienyl

$\mathrm{R}^{3}=2$-pyridyl

$\mathrm{R}^{3}=2$-salicylidene<smiles>O=C(O)c1ccccc1/N=C/c1cccs1</smiles><smiles>Oc1ccccc1/C=N/c1cccc2cccnc12</smiles><smiles>[R]ON=C1CCCCC1=NO[R4]</smiles>
$R^{4}$<smiles>[R7]O/N=C/c1ccccc1O</smiles>

$$
\mathrm{R}^{6}=\mathrm{H} \quad \text { L41 }
$$

$\mathrm{R}^{6}=\mathrm{CH}_{3} \mathbf{L} 42$<smiles>[R9]ON=Cc1cccs1</smiles>

$\mathrm{R}^{4}=\mathrm{H} \quad \mathrm{L} 40 \quad \mathrm{R}^{5}=\mathrm{CH}_{3} \quad \mathbf{L} 36$ $\mathrm{R}^{5}=\mathrm{H} \quad \mathrm{L} 37$
$\mathrm{R}_{-\mathrm{N}^{-}}^{7} \mathrm{R}^{7}$<smiles>Ic1cccc2cccnc12</smiles>

$\mathrm{R}^{7}=\mathrm{CH}_{3} \quad \mathrm{~L} 43$<smiles>Nc1ccccn1</smiles>

L45

$\mathrm{H}_{3} \mathrm{C}-\mathrm{NH} \mathrm{HN}-\mathrm{CH}_{3}$

L46<smiles>CON(C)C(=O)C(=O)N(C)OC</smiles><smiles>CC(=NO)C(C)=NO</smiles>

$\mathrm{R}^{7}=\mathrm{H}$

L44<smiles>Cc1ccc2ccc3ccc(C)nc3c2n1</smiles><smiles>CCC(C)C(=O)C1CCCCC1=O</smiles>

$\mathrm{CuBr} \cdot \mathrm{SMe}_{2}$

L51

$\left(\mathrm{CulPPh}_{3}\right)_{4}$

L52<smiles>CC(=O)c1ccccn1</smiles><smiles>CCOC(=O)c1c(N)sc(C(C)=O)c1C</smiles><smiles>NCC(=O)NCC(=O)NCC(=O)O</smiles><smiles>O=C(CSc1ccccn1)c1ccccc1</smiles>

Figure 2: Ligands that were subjected to the ligand screening

avoid this complication, the $N, N$-dimethylated derivative $\mathbf{L 4 3}$ was synthesized and turned out to exhibit an improved catalytic activity compared to L44. Since L1 showed high catalytic activity, its 2,2-dimethylated analogue $\mathbf{L} \mathbf{5}$ and the structurally related pyrrolidino- and piperidinoacetic acids $\mathbf{L 9}$ and $\mathbf{L 1 5}$ were tested, but even these minor modifications of the ligand structure led to a drastically decreased catalytic activity.

Interestingly, not only the $N, P$-chelating phosphinite ligands $\mathbf{L 1 9}$ and $\mathbf{L 2 0}$ but also the $N, O$-chelating phosphonate ligand 
Table 1: Effect of base, molecular sieves and solvent on the coupling of 4-bromoanisole and 4-methoxyphenol with L1. ${ }^{\mathrm{a}}$

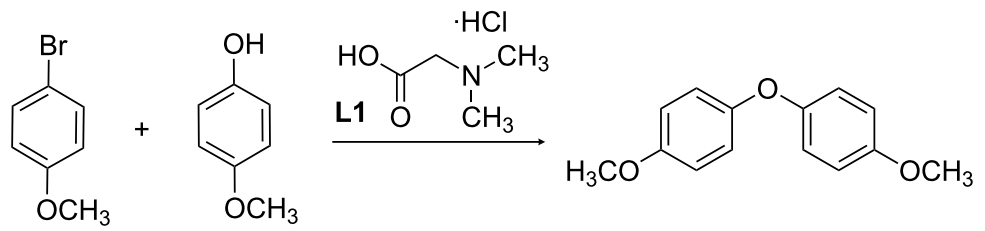

\begin{tabular}{llllll}
\hline entry & base & drying agent & Cul (mol \%) & solvent & \multicolumn{1}{l}{$\begin{array}{l}\text { ratio of } \\
\text { 4-bromoanisole/product }\end{array}$} \\
\hline 1 & $\mathrm{Cs}_{2} \mathrm{CO}_{3}$ & - & 10 & $\begin{array}{l}\text { toluene }^{\mathrm{b}} \\
\text { toluene }\end{array}$ & no conversion $^{\mathrm{c}}$ \\
2 & $\mathrm{Cs}_{2} \mathrm{CO}_{3}$ & $\mathrm{MS} 4 \AA$ & 5 & conversion $^{\mathrm{c}}$ \\
3 & $\mathrm{Cs}_{2} \mathrm{CO}_{3}$ & $\mathrm{MS} 4 \AA$ & 10 & toluene $^{\mathrm{b}}$ & conversion $^{\mathrm{c}}$ \\
4 & $\mathrm{Cs}_{2} \mathrm{CO}_{3}$ & $\mathrm{MgSO}_{4}$ & 10 & Meluene & traces $^{\mathrm{b}}$ \\
5 & $\mathrm{~K}_{3} \mathrm{PO}_{4}$ & - & 10 & $1,4-$ dioxane $^{\mathrm{f}}$ & $8: 1^{\mathrm{e}}$ \\
6 & $\mathrm{~K}_{3} \mathrm{PO}_{4}$ & - & 10 & toluene & $9: 1^{\mathrm{e}}$ \\
7 & $\mathrm{~K}_{3} \mathrm{PO}_{4}$ & - & 10 & $2: 1^{\mathrm{e}}$ \\
\hline
\end{tabular}

aReaction conditions: base (2.0 equiv), Cul (10 mol \%), L1 (10 mol \%), 4-methoxyphenol (1.00 mmol, 1.0 equiv), 4-bromoanisole (1.00 mmol, 1.0 equiv), solvent $(0.6 \mathrm{~mL})$, argon atmosphere; ${ }^{\mathrm{b}} 110{ }^{\circ} \mathrm{C}$; ' judged by TLC; $80{ }^{\circ} \mathrm{C}$; ${ }^{e}$ determined by ${ }^{1} \mathrm{H}$ NMR; ${ }^{\mathrm{f}} 100{ }^{\circ} \mathrm{C}$.

\begin{tabular}{|c|c|c|c|c|c|}
\hline \multirow[b]{2}{*}{ entry } & \multirow[b]{2}{*}{ ligand } & $\underbrace{+1}_{\mathrm{OCH}_{3}}$ & $\begin{array}{c}\text { Cul }(10 \mathrm{~mol} \%) \\
\text { ligand }(10 \mathrm{~mol} \%) \\
\underset{\mathrm{K}_{3} \mathrm{PO}_{4}(2.0 \text { equiv })}{\mathrm{MeCN}}\end{array}$ & \multirow[b]{2}{*}{ ligand } & \multirow[b]{2}{*}{ ratio 4-bromoanisole/product ${ }^{b}$} \\
\hline & & ratio 4-bromoanisole/product ${ }^{b}$ & entry & & \\
\hline 1 & L1 & $8: 1$ & 29 & L29 & $20: 1$ \\
\hline 2 & L2 & $12: 1$ & 30 & L30 & $31: 1$ \\
\hline 3 & L3 & $15: 1$ & 31 & L31 & no conversion \\
\hline 4 & L4 & $18: 1$ & 32 & L32 & no conversion \\
\hline 5 & L5 & $19: 1$ & 33 & L33 & no conversion \\
\hline 6 & L6 & $20: 1$ & 34 & L34 ${ }^{e}$ & $15: 1$ \\
\hline 7 & L7 & $20: 1$ & 35 & L35 & $18: 1$ \\
\hline 8 & L8 & $20: 1$ & 36 & L36 & $20: 1$ \\
\hline 9 & L9 & $21: 1$ & 37 & L37 & $20: 1$ \\
\hline 10 & L10 & $21: 1$ & 38 & L38 & $20: 1$ \\
\hline 11 & L11 & $26: 1$ & 39 & L39 & $24: 1$ \\
\hline 12 & L12 & $27: 1$ & 40 & $L 40^{f}$ & $28: 1$ \\
\hline 13 & L13 & $29: 1$ & 41 & L41 & traces \\
\hline 14 & L14 & $30: 1$ & 42 & L42 & traces \\
\hline 15 & L15 & $32: 1$ & 43 & L43 & $13: 1$ \\
\hline 16 & $\mathrm{~L}^{\mathrm{c}} \mathrm{c}$ & $40: 1$ & 44 & L44 & $15: 1$ \\
\hline 17 & $L 17^{d}$ & traces & 45 & L45 & $24: 1$ \\
\hline 18 & L18 & no conversion & 46 & L46 & $24: 1$ \\
\hline 19 & L19 & $12: 1$ & 47 & L47 & $15: 1$ \\
\hline 20 & L20 & $12: 1$ & 48 & L48 & $12: 1$ \\
\hline 21 & L21 & $15: 1$ & 49 & L49 & traces \\
\hline 22 & L22 & $25: 1$ & 50 & L50 & $23: 1$ \\
\hline 23 & L23 & $40: 1$ & 51 & L519 & $15: 1$ \\
\hline 24 & L24 & traces & 52 & L529 & $15: 1$ \\
\hline
\end{tabular}




\begin{tabular}{|llllll}
\hline \multicolumn{2}{|c|}{ Table 2: Short-term screening. ${ }^{\text {a }}$ (continued) } & & & \\
\hline 25 & L25 & traces & 53 & L53 & $21: 1$ \\
26 & L26 & traces & 54 & L54 & $27: 1$ \\
27 & L27 & no conversion & 55 & L55 & traces \\
28 & L28 & $17: 1$ & 56 & L56 & no conversion \\
\hline
\end{tabular}

areaction conditions: $\mathrm{K}_{3} \mathrm{PO}_{4}$ (2.0 equiv), Cul (10 mol \%), ligand (10 mol \%), 4-methoxyphenol (1.00 mmol, 1.0 equiv), 4-bromoanisole (1.00 mmol, 1.0 equiv), MeCN ( $3 \mathrm{~mL}), 80^{\circ} \mathrm{C}$, argon atmosphere; betermined by ${ }^{1} \mathrm{H} \mathrm{NMR}$; ctime: $2 \mathrm{~h}$; ${ }^{\mathrm{d}}$ time: $2 \mathrm{~h} 35 \mathrm{~min}$; etime: $3 \mathrm{~h}$; ${ }^{\mathrm{f}}$ time: $2 \mathrm{~h} 40 \mathrm{~min}$; gtime: 2 h 25 min.

L21 showed a significant catalytic activity. From the group of diimine ligands, $\mathbf{L 2 8}$ [30] gave the best results. It should be noted that also in this class, structurally related ligands showed drastically different catalytic activities in the screening, as can be seen by comparison of $\mathbf{L 2 8}, \mathbf{L 3 2}$, and L33. Furthermore, oxime ethers, which, to the best of our knowledge, represent a new class of ligands for Ullmann-type couplings, were also screened in the model reaction. All tested oxime ethers and oximes showed catalytic activity, although the substrate conversion was lower compared to the amino acid-derived ligands. The catalytic activities of the oximes did not, however, differ from those of the oxime ethers. On the other hand, the salicyl aldehyde-derived oxime ether and oxime ligands [31] showed only poor substrate conversions in comparison to other classes of multidentate ligands. $\mathbf{L 4 8}$ also proved to possess a high catalytic activity, which is consistent with the results reported by Beller et al. [32] who used the ligand for the synthesis of various diaryl ethers. In the short-term screening, none of the tested ligands showed a higher substrate conversion than L1 did.

The most promising ligands of the short-term screening were subsequently subjected to a long-term screening ( $24 \mathrm{~h})$ to examine their thermal and chemical stability (Table 3 , Figure 3).

In the long-term screening the ligands $\mathbf{L 2}, \mathbf{L 4 3}$ and $\mathbf{L 4 8}$ showed promising results since their substrate conversions were only slightly lower than that of $\mathbf{L} \mathbf{1}$, which again was unsurpassed. The phosphinite ligands $\mathbf{L 1 9}$ and L20, which showed comparable catalytic activities to $\mathbf{L 2}, \mathbf{L 4 3}$ and $\mathbf{L 4 8}$ in the short-term screening, in comparison gave lower substrate conversions in the long-term screening. This decrease of catalytic activity may be due to oxidation and subsequent hydrolysis of the air- and water-sensitive phosphinites to their corresponding phosphinic acids and 8-hydroxyquinoline (L47), which showed a compa-

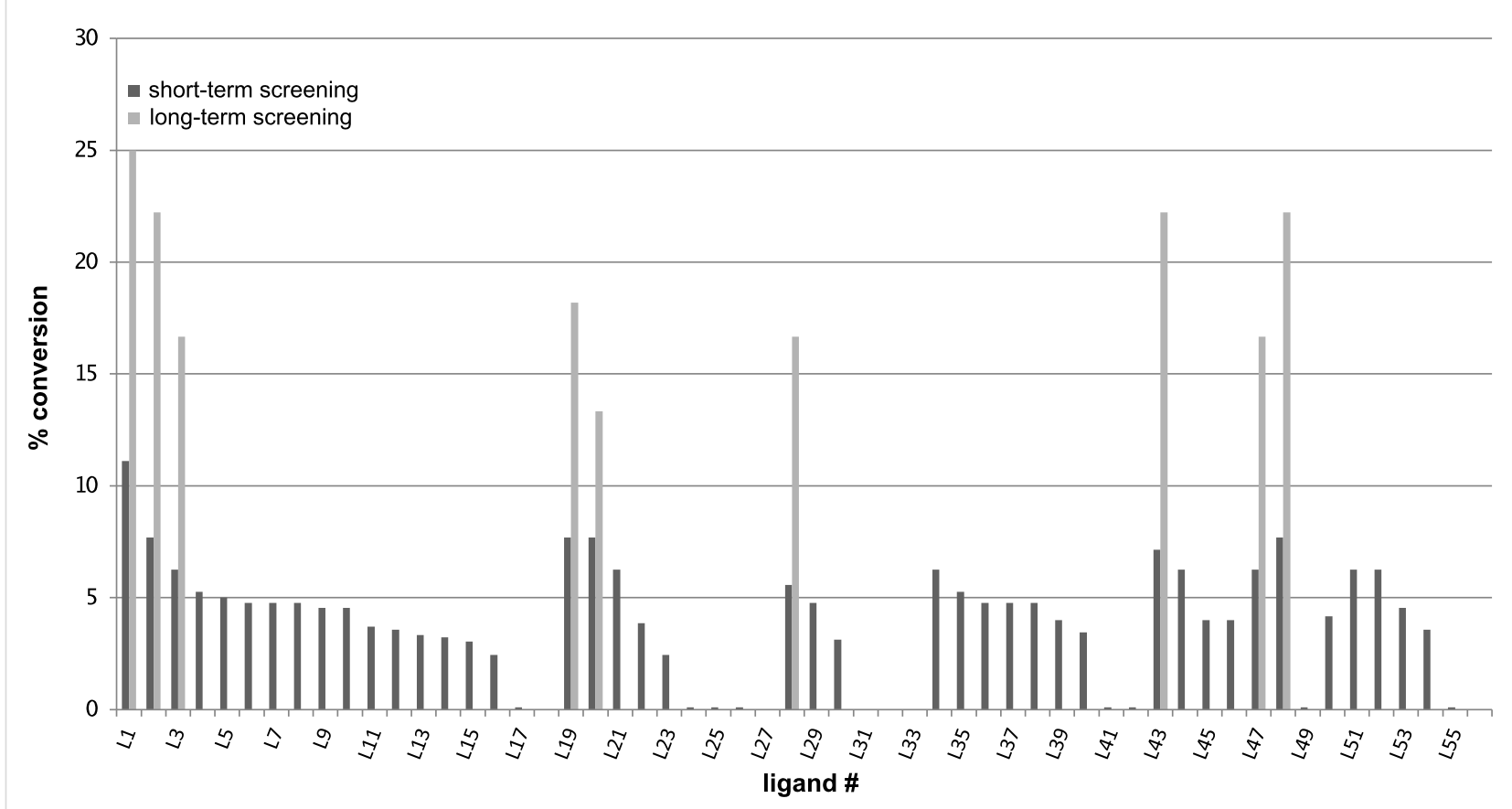

Figure 3: Conversions of the model reaction versus the ligand numbers. For structures of the ligands refer to Figure 2. 


\begin{tabular}{|c|c|c|c|c|c|c|c|}
\hline \multirow[b]{2}{*}{ entry } & \multirow[b]{2}{*}{ ligand } & \multirow[b]{2}{*}{ time } & \multicolumn{2}{|c|}{$\begin{array}{c}\text { Cul }(10 \mathrm{~mol} \%) \\
\text { ligand }(10 \mathrm{~mol} \%)\end{array}$} & \multirow[b]{2}{*}{ ligand } & \multirow[t]{2}{*}{$\mathrm{OCH}_{3}$} & \multirow[b]{2}{*}{ ratio $^{b}$} \\
\hline & & & ratio $^{b}$ & entry & & & \\
\hline 1 & L1 & $\begin{array}{l}2 \mathrm{~h} 15 \mathrm{~min} \\
24 \mathrm{~h}\end{array}$ & $\begin{array}{l}8: 1 \\
3: 1\end{array}$ & 5 & L20 & $\begin{array}{l}2 \mathrm{~h} 15 \mathrm{~min} \\
24 \mathrm{~h}\end{array}$ & $\begin{array}{l}12: 1 \\
6.5: 1\end{array}$ \\
\hline 2 & L2 & $\begin{array}{l}2 \mathrm{~h} 15 \mathrm{~min} \\
24 \mathrm{~h}\end{array}$ & $\begin{array}{l}12: 1 \\
3.5: 1\end{array}$ & 6 & L28 & $\begin{array}{l}2 \mathrm{~h} 15 \min \\
3 \mathrm{~h} 15 \mathrm{~min} \\
24 \mathrm{~h}\end{array}$ & $\begin{array}{l}17: 1 \\
9: 1 \\
5: 1\end{array}$ \\
\hline 3 & L3 & $\begin{array}{l}2 \mathrm{~h} 15 \mathrm{~min} \\
24 \mathrm{~h}\end{array}$ & $\begin{array}{l}15: 1 \\
5: 1\end{array}$ & 7 & L43 & $\begin{array}{l}2 \mathrm{~h} 15 \mathrm{~min} \\
24 \mathrm{~h}\end{array}$ & $\begin{array}{l}13: 1 \\
3.5: 1\end{array}$ \\
\hline \multirow[t]{2}{*}{4} & L19 & $\begin{array}{l}2 \mathrm{~h} 15 \mathrm{~min} \\
24 \mathrm{~h}\end{array}$ & $\begin{array}{l}12: 1 \\
4.5: 1\end{array}$ & 8 & L47 & $\begin{array}{l}2 \mathrm{~h} 15 \mathrm{~min} \\
24 \mathrm{~h}\end{array}$ & $\begin{array}{l}15: 1 \\
5: 1\end{array}$ \\
\hline & & & & 9 & L48 & $\begin{array}{l}2 \mathrm{~h} 15 \mathrm{~min} \\
24 \mathrm{~h}\end{array}$ & $\begin{array}{l}12: 1 \\
3.5: 1\end{array}$ \\
\hline
\end{tabular}

aReaction conditions: $\mathrm{K}_{3} \mathrm{PO}_{4}$ (2.0 equiv), Cul (10 mol \%), ligand (10 mol \%), 4-methoxyphenol (1.00 mmol, 1.0 equiv), 4-bromoanisole (1.00 mmol, 1.0 equiv), $\mathrm{MeCN}(3 \mathrm{~mL}), 80^{\circ} \mathrm{C}$; b ratio of 4 -bromoanisole to product, determined by ${ }^{1} \mathrm{H} \mathrm{NMR}$.

rable catalytic activity. It was found that the conversion within a specific time interval decreased over time stronger than anticipated, and finally the reaction ceased. The stagnation may be due to the formation of traces of water in the reaction mixture or formation of a catalytically less active copper(I)-bromide complex from liberated bromide ions. Another alternative may be the decomposition of the ligands.

\section{Conclusion}

A collection of 56 multidentate ligands were screened in a model system for the Ullmann diaryl ether synthesis of electron-rich phenols and aryl bromides. Structurally diverse ligands showed a catalytic activity in the coupling, but none of the ligands showed a higher catalytic activity than $N, N$ dimethylglycine (L1). In the long-term screening, the ligands L2, L43 and L48 were found to exhibit only slightly lower catalytic activity than $\mathbf{L} \mathbf{1}$ in the model reaction. In conclusion, $\mathrm{N}$-methylated amino acid-derived $\mathrm{N}, \mathrm{O}$-ligands, $\mathrm{N}, \mathrm{N}$-ligands with small bite angles, and $N$-butylimidazole proved to be the most efficient ligands for Ullmann diaryl ether formation under the tested conditions. The synthesized phosphinite-type $P, N$ ligands derived from 8-hydroxyquinoline performed well in the short-term screening but lost catalytic activity over time. While active ligands were found in various structural classes, even relatively small variations of the efficient ligands can lead to a dramatic loss of catalytic activity, which complicates their rational optimization. In general, strongly chelating ligands with four coordinating atoms should be avoided. Coordination of the copper atom by one $\mathrm{N}$ - and one $\mathrm{N}$ - or O-atom may be a desirable structural motif for the design of new ligands. Remarkably, published ligands used for other C-heteroatom bond-formation reactions showed unexpected low activity in our system.

\section{Experimental \\ General procedure for model reactions of the ligand screening}

A dried reaction tube (diameter $1.5 \mathrm{~cm}$ ) equipped with a stirring bar (length $0.6 \mathrm{~cm}$ ) is charged with anhydrous $\mathrm{K}_{3} \mathrm{PO}_{4}$ (430 mg, $2.00 \mathrm{mmol}, 2.0$ equiv) under an argon atmosphere in counterflow. CuI (14 mg, $0.10 \mathrm{mmol}, 10 \mathrm{~mol} \%)$, ligand (0.10 mmol, $10 \mathrm{~mol} \%$ ), 4-methoxyphenol (124 mg, $1.00 \mathrm{mmol}$, 1.0 equiv), 4-bromoanisole ( $130 \mu \mathrm{L}, 187 \mathrm{mg}, 1.00 \mathrm{mmol}$, 1.0 equiv) and $1 \mathrm{~mL}$ of anhydrous acetonitrile is subsequently added, and the tube is sealed with a septum and equipped with an argon balloon. The reaction mixture is stirred for $30 \mathrm{~min}$ at room temperature and is then placed in a heating bath at $80{ }^{\circ} \mathrm{C}$. Samples of $500 \mu \mathrm{L}$ of the reaction mixture are taken after $2 \mathrm{~h} 15 \mathrm{~min}$ and $24 \mathrm{~h}$. The samples are filtered over Celite and washed with dichloromethane, and the filtrate is evaporated in vacuo. The conversion of starting material is determined by ${ }^{1} \mathrm{H}$ NMR spectroscopy.

\section{Supporting Information}

\section{Supporting Information File 1}

Experimental procedures and characterization data of ligands and starting materials.

[http://www.beilstein-journals.org/bjoc/content/ supplementary/1860-5397-8-122-S1.pdf] 


\section{Acknowledgements}

We thank Dr. J. C. Liermann (Mainz) for NMR spectroscopy.

\section{References}

1. Ley, S. V.; Thomas, A. W. Angew. Chem., Int. Ed. 2003, 42 , 5400-5449. doi:10.1002/anie.200300594

2. Frlan, R.; Kikelj, D. Synthesis 2006, 2271-2285. doi:10.1055/s-2006-942440

3. Sheldrick, G. M.; Jones, P. G.; Kennard, O.; Williams, D. H.; Smith, G. A. Nature 1978, 271, 223-225. doi:10.1038/271223a0

4. Nicolaou, K. C.; Mitchell, H. J.; Jain, N. F.; Winssinger, N.; Hughes, R.; Bando, T. Angew. Chem., Int. Ed. 1999, 38, 240-244. doi:10.1002/(SICI)1521-3773(19990115)38:1/2<240::AID-ANIE240>3.0 .CO;2-5

5. Teuscher, E.; Melzig, M. F.; Lindequist, U. Biogene Arzneimittel, 6th ed.; Wissenschaftliche Verlagsgesellschaft: Stuttgart, Germany, 2004.

6. Manske, R. H. F.; Holmes, H. L. The Alkaloids-Chemistry \& Physiology; Academic Press Publishers: New York, 1954; Vol. 4.

7. Tamai, S.; Kaneda, M.; Nakamura, S. J. Antibiot. 1982, 35, 1130-1136. doi:10.7164/antibiotics.35.1130

8. Ullmann, F. Ber. Dtsch. Chem. Ges. 1904, 37, 853-854. doi:10.1002/cber.190403701141

9. Ullmann, F.; Sponagel, P. Ber. Dtsch. Chem. Ges. 1905, 38, 2211-2212. doi:10.1002/cber.190503802176

10. Aranyos, A.; Old, D. W.; Kiyomori, A.; Wolfe, J. P.; Sadighi, J. P.; Buchwald, S. L. J. Am. Chem. Soc. 1999, 121, 4369-4378. doi:10.1021/ja990324r

11. Kuwabe, S.; Torraca, K. E.; Buchwald, S. L. J. Am. Chem. Soc. 2001, 123, 12202-12206. doi:10.1021/ja012046d

12. Hartwig, J. F. Angew. Chem., Int. Ed. 1998, 37, 2046-2067. doi:10.1002/(SICI)1521-3773(19980817)37:15<2046::AID-ANIE2046>3 .0.CO;2-L

13. Mann, G.; Incarvito, C.; Rheingold, A. L.; Hartwig, J. F. J. Am. Chem. Soc. 1999, 121, 3224-3225. doi:10.1021/ja984321a

14. Kunz, K.; Scholz, U.; Ganzer, D. Synlett 2003, 2428-2439. doi:10.1055/s-2003-42473

15. Weingarten, H. J. Org. Chem. 1964, 29, 3624-3626. doi:10.1021/jo01035a046

16. Paine, A. J. J. Am. Chem. Soc. 1987, 109, 1496-1502. doi:10.1021/ja00239a032

17. Capdevielle, P.; Maumy, M. Tetrahedron Lett. 1993, 34, 1007-1010. doi:10.1016/S0040-4039(00)77477-6

18. Taillefer, M.; Cristau, H. J.; Cellier, P. P.; Spindler, J. F.; Ouali, A. Relatively low-temperature catalytic procedure for arylation or vinylation of nitrogen-containing nucleophilic compounds. WO Patent 2003053885, July 3, 2003.

19. Taillefer, M.; Cristau, H. J.; Cellier, P. P.; Spindler, J. F. Process for arylation, vinylation or alkynylation of nucleophilic compounds, in particular nitrogen-containing nucleophiles. WO Patent 2003101966, Dec 11, 2003.

20. Buchwald, S. L.; Klapars, A.; Antilla, J. C.; Job, G. E.; Wolter, M.; Kwong, F. Y.; Nordmann, G.; Hennessy, E. J. Copper-Catalyzed Formation of Carbon-Heteroatom and Carbon-Carbon Bonds. U.S. Patent 6759554, July 6, 2004.

21. Fagan, P. J.; Hauptman, E.; Shapiro, R.; Casalnuovo, A. J. Am. Chem. Soc. 2000, 122, 5043-5051. doi:10.1021/ja000094c

22. Zhang, H.; Cai, Q.; Ma, D. J. Org. Chem. 2005, 70, 5164-5173. doi:10.1021/j00504464
23. Monnier, F.; Taillefer, M. Angew. Chem. 2009, 121, 7088-7105. doi:10.1002/ange. 200804497

24. Buck, E.; Song, Z. J.; Tschaen, D.; Dormer, P. G.; Volante, R. P.; Reider, P. J. Org. Lett. 2002, 4, 1623-1626. doi:10.1021/ol025839t

25. Cai, Q.; Zhu, W.; Zhang, H.; Zhang, Y.; Ma, D. Synthesis 2005, 496-499. doi:10.1055/s-2004-831196

26. Blank, N.; Opatz, T. J. Org. Chem. 2011, 76, 9777-9784. doi:10.1021/jo201871c

27. Liu, Y.-H.; Li, G.; Yang, L.-M. Tetrahedron Lett. 2009, 50, 343-346. doi:10.1016/j.tetlet.2008.11.005

28. Maiti, D.; Buchwald, S. L. J. Org. Chem. 2010, 75, 1791-1794. doi:10.1021/jo9026935

29. Yamakawa, K. Process for Producing Alkoxybenzene Compound and Aryloxybenzene Compound. U.S. Patent 5006660, April 9, 1991

30. Hosseinzadeh, R.; Golchoubian, H.; Masoudi, M. J. Chin. Chem. Soc. 2008, 55, 649-653.

31. Cristau, H.-J.; Cellier, P. P.; Hamada, S.; Spindler, J.-F.; Taillefer, M. Org. Lett. 2004, 6, 913-916. doi:10.1021/ol036290g

32. Schareina, T.; Zapf, A.; Cotté, A.; Müller, N.; Beller, M. Tetrahedron Lett. 2008, 49, 1851-1855. doi:10.1016/j.tetlet.2008.01.036

\section{License and Terms}

This is an Open Access article under the terms of the Creative Commons Attribution License (http://creativecommons.org/licenses/by/2.0), which permits unrestricted use, distribution, and reproduction in any medium, provided the original work is properly cited.

The license is subject to the Beilstein Journal of Organic Chemistry terms and conditions:

(http://www.beilstein-journals.org/bjoc)

The definitive version of this article is the electronic one which can be found at: doi:10.3762/bjoc. 8.122 